\title{
Factors Related with Sexually Transmitted Diseases (STDs) on Women Patients at The Pekauman Banjarmasin Health Service Centers
}

\author{
$1^{\text {st }}$ Ika Mardiatul Ulfa ${ }^{1}, 2^{\text {nd }}$ Nurul Hidayah ${ }^{2}$ \\ \{icka_ulfa86@yahoo.com ${ }^{1}$ \} \\ "Diploma of Midwifery Faculty of Health University Sari Mulia, South Kalimantan, Indonesia
}

\begin{abstract}
Sexually Transmitted Diseases (STDs) was a public health problem in terms of health, political, social and economic. In south Kalimantan cases of sexually transmitted diseases, specially HIV / AIDS cases has increased from 2012 to 2014. This research aims to study and explain about the incidence of Sexually Transmitted Diseases (STDs) on women patients at the Pekauman Banjarmasin Health Service Centers in 2015. The research design is case control by retrospective analyze approach with mixs method which is quantitative used secunder data and qualitative used primary data by indepth interview on to 5 informan who suffering STDs. Sample was taken with ratio 1:1 which 69 total sampling case, 69 control by systematic random sampling. The results of the research there are corelation between age, education and parity with the incidence of STDs with a p-value of age is $0,001,0,035$ education and parity 0,007 . While the variable profesian and marital status are not related. The most dominant variable related to the incidence of STDs is variable ages with OR 3,207 . While the results obtained an average interview informants knowledge about STDs and prevention is still lacking and risky sexual behavior are still high. The suggestion given is for health centers to further promote Pekauman counseling about STDs and how to prevent STDs and safe sex behavior, especially among women sex workers in the region Pekauman Banjarmasin Health Service Centers.
\end{abstract}

Keywords: Age, Education, Parity and Sexually Transmitted Diseases

\section{Introduction}

Sexually Transmitted Diseases (STDs) are still a public health problem both in terms of health, politics, and social economy. In the past decade, there has been an increase in the incidence of STIs in many countries in the world. Failure in diagnosis, as well as therapy at an early stage, 
results in the emergence of serious complications, such as infertility, ectopic pregnancy, fetal death, neonatal infection, infants and low birth weight, anogenital cancer, can even cause death[5].

Sexually transmitted diseases cause infections of the reproductive tract which must be taken seriously. If not treated properly, the infection can spread and cause suffering, prolonged illness, infertility and death. The impact of PMS on pregnancy depends on the causative organism, duration of infection, and gestational age at the time the woman is infected. Unhealthy conceptions often result from PMS, such as fetal death (spontaneous abortion or stillbirth), low birth weight babies (due to prematurity or retardation of fetal growth in the womb), and congenital or perinatal infections (blindness, neonatal pneumonia, and mental retardation)[2].

World Health Organization (WHO) in 2011 estimated that every year there were 350 million new STI sufferers in developing countries in Africa, Asia, Southeast Asia and Latin America. In developing countries STI infections and complications are one of the five main reasons for the high morbidity (Febiyantin, 2014). In 2011, there were 448 million new cases of sexually transmitted infections (syphilis, gonorrhea, Chlamydia, and trichomonas) that occurred in adults aged 15-49 years. This does not include HIV and other sexually transmitted infections that continue and affect the lives of individuals and communities in the world. In developing countries the prevalence of sexually transmitted diseases is still relatively high. One of the developing countries, namely Indonesia, sexually transmitted diseases has a prevalence ranging from $7.4 \%$ 50\%, the highest incidence in Papua[14,6].

The current incidence of PMS tends to increase in Indonesia. Its source is difficult to trace, because no registration has been made of patients found. The number of sufferers recorded is only a small part of the total number of sufferers. The groups at risk for STDs are the reproductive age group, travelers or sailors, commercial sex workers (CSWs), drug addicts and homosexuals[2].

In South Kalimantan cases of sexually transmitted diseases, especially cases of HIV / AIDS have increased from 2012 to 2014. In 2012 there were 88 cases, 2013 were 174 cases and increased in 2014 which was 227 cases[8].

Factors that can affect the incidence of sexually transmitted diseases. is age, which is one of the important variables in influencing a person's sexual activities so that in conducting sexual activities an older person has more consideration than an immature person. The younger the WPS age group, the higher the prevalence of STIs[1].

Similar research conducted by Artika (2009), that one of the factors that can influence the emergence of sexually transmitted diseases is age and education. The older a person is, the more experience will be gained. Respondents who have knowledge in both categories are more than 24 years old. And the higher one's education and one's knowledge will be more extensive or better, besides that the higher the education, the easier it is for someone to obtain information[1].

About $12 \%$ of women aged $15-49$ years old and $1 \%$ of married men aged 15-54 years who have had active sexual relations reported having an STI and / or symptoms in the 12 months prior to the survey[8].

In Banjarmasin, South Kalimantan, the number of sufferers of sexually transmitted infections (STIs) continues to increase based on data from the Health Service, recorded 231 cases. age of students, between junior high school students and high school students. This was revealed by the Banjarmasin City Health Office[3].

Based on the report of the treatment program at the STI clinic (2010) Puskesmas II Baturaden, several factors that influence the high incidence of PMS in the Localization of 
Baturaden Region include: lack of health promotion, awareness of sex workers to regularly visit the STI clinic every month is still low, knowledge and awareness of CSWs towards PMS is still lacking and treatment of PMS is not perfect[12].

Data from the Banjarmasin City Service all Puskesmas in the Banjarmasin City area have implemented the $7 \mathrm{~T}$ program but not all items have been implemented properly, especially regarding PMS screening. One of the Puskesmas that has routinely carried out PMS checks is the PekaumanPuskesmas in the city area of South Banjarmasin. In addition, the Pekauman Health Center is a referral from another Health Center in the city of Banjarmasin because it is considered a Health Center that has more complete facilities before being referred to the Hospital. Data from the Puskesmas obtained from the laboratory, an increase in the number of patients undergoing the examination, both female and male patients. In 2014 there were $47(6.5 \%)$ patients diagnosed with PMS, and in 2015 the period from January to September increased to 69 (10.2\%) patients diagnosed with PMS[4].

Based on these data, this study was conducted with the aim of studying and explaining the incidence of sexually transmitted diseases (STDs) in female patients in the Banjarmasin Pekauman Health Center in 2015.

\section{Materials And Methods}

The research design used is case control and retrospective analysis approach with mix method method which is quantitative using secondary data and qualitative using primary data through indepth interview. The population in this study were all female patients who examined at the BanjamasinPekauman Health Center Laboratory in the January-September 2015 period with a total case population of 69 people and a control population of 606 people. Samples were taken with a ratio of 1: 1 ie 69 cases in total sampling and 69 controls with systematic random sampling, qualitative samples were taken 5 informants affected by PMS.

\section{Results And Discussion}

\subsection{Result of Univariate analysis}

Table of Frequency Distribution of respondents based on the incidence of PMS, Age, Education, Occupation, Parity and Marital Status in Female Patients in Pekauman Health Center Banjarmasin

\begin{tabular}{|c|c|c|c|c|c|c|}
\hline \multirow[t]{2}{*}{ Variable } & \multirow{2}{*}{$\frac{\text { Case }}{\mathrm{n}}$} & \multicolumn{2}{|c|}{$\begin{array}{c}\text { Contr } \\
\text { ol }\end{array}$} & $\sum$ & \multirow[b]{2}{*}{$\mathrm{n}$} & \multirow[b]{2}{*}{$\%$} \\
\hline & & $\%$ & $\mathrm{n}$ & $\%$ & & \\
\hline \multicolumn{7}{|c|}{$\begin{array}{l}\text { Incident of } \\
\text { PMS }\end{array}$} \\
\hline 1. PMS & 69 & 50 & - & . & & \\
\hline $\begin{array}{ll}\text { 2. } & \text { Not } \\
& \text { PMS } \\
\end{array}$ & - & - & $\begin{array}{l}6 \\
9 \\
\end{array}$ & $\begin{array}{l}5 \\
0\end{array}$ & 138 & $\begin{array}{l}10 \\
0\end{array}$ \\
\hline
\end{tabular}


Age

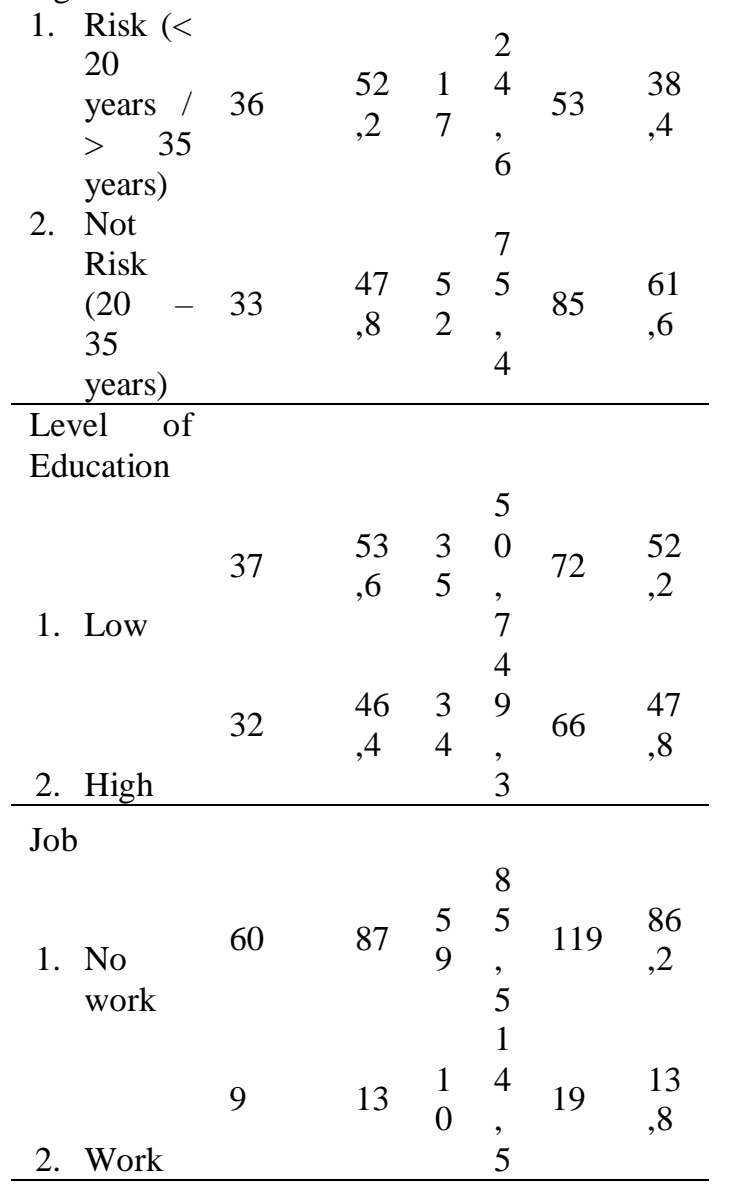

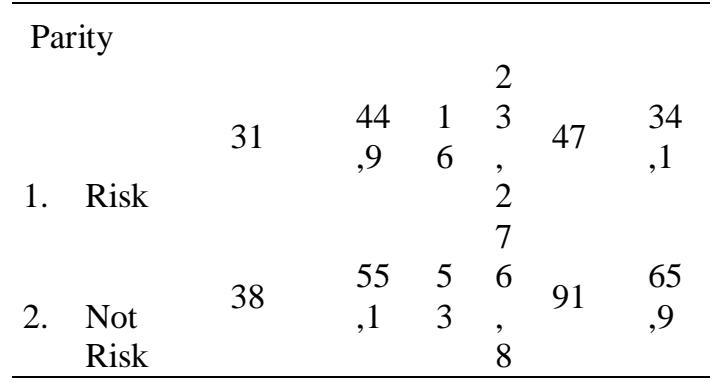

\begin{tabular}{lcccccc}
\hline Marital & & & & & & \\
Status & & & & & & \\
1. Not & 10 & 14 & 1 & 2 & 24 & 17 \\
$\quad$ married & &, 5 & 4 & 0 & &, 4
\end{tabular}




\begin{tabular}{lllllll} 
/Divorc & & & & & \\
ed & & & & 3 & & \\
& & & & 7 & & \\
& & 85 & 5 & 9 & 114 & 82 \\
2. & & & \\
Marrie & 59 &, 5 & 5 &, & &, 6 \\
d & & & & 7 & & \\
\hline
\end{tabular}

3.2 Result of Bivariate analysis

Bivariate analysis result can be seen in the table:

\begin{tabular}{|c|c|c|c|c|c|c|c|}
\hline \multirow[t]{3}{*}{$\begin{array}{l}\text { Vari } \\
\text { able }\end{array}$} & & \multicolumn{3}{|c|}{ Incident of PMS } & \multirow{2}{*}{\multicolumn{2}{|c|}{$P$-value }} & \multirow{2}{*}{$\begin{array}{l}\text { OR } \\
(\mathrm{CI} \\
95 \%)\end{array}$} \\
\hline & & \multicolumn{2}{|c|}{ PMS } & $\begin{array}{l}\text { Not } \\
\text { PM } \\
\text { S }\end{array}$ & & & \\
\hline & & $\mathrm{n}$ & $\%$ & $\mathrm{n}$ & \multicolumn{2}{|l|}{$\%$} & \\
\hline \multirow[t]{3}{*}{ Age } & $\begin{array}{l}\text { Risk }(<20 \\
\text { years / > 35 } \\
\text { years) }\end{array}$ & 36 & 52,2 & 17 & 24,6 & \multirow{3}{*}{10} & \multirow{3}{*}{$\begin{array}{l}3,337 \\
(1,619- \\
6,877)\end{array}$} \\
\hline & $\begin{array}{l}\text { Not Risk } \\
(20-35 \\
\text { years })\end{array}$ & 33 & 47,8 & 52 & 75,4 & & \\
\hline & Total & 69 & 100 & 69 & 100 & & \\
\hline \multirow{4}{*}{$\begin{array}{l}\text { Leve } \\
1 \\
\text { Edu } \\
\text { catio } \\
\mathrm{n}\end{array}$} & & 37 & 53,6 & 49 & 71 & \multirow{3}{*}{$\begin{array}{l}0,0 \\
35\end{array}$} & \multirow{3}{*}{$\begin{array}{l}0,472 \\
(0,234- \\
0,953)\end{array}$} \\
\hline & $\begin{array}{l}\text { Low (SD- } \\
\text { SMP) }\end{array}$ & & & & & & \\
\hline & $\begin{array}{l}\text { High } \\
\text { (SMA-PT) }\end{array}$ & 32 & 46,4 & 20 & 29 & & \\
\hline & Total & 69 & 100 & 69 & 100 & & \\
\hline \multirow[t]{3}{*}{ Job } & Not Work & 60 & 87 & 59 & 85,5 & \multirow[t]{2}{*}{$\begin{array}{l}0,8 \\
05\end{array}$} & \multirow[t]{2}{*}{$\begin{array}{l}1,130 \\
(0,429 \\
2,980)\end{array}$} \\
\hline & Work & 9 & 13 & 10 & 14,5 & & \\
\hline & Total & 69 & 100 & 69 & 100 & & \\
\hline $\begin{array}{l}\text { Parit } \\
\mathrm{y}\end{array}$ & Risk $(\geq 4)$ & 31 & 45 & 16 & 23,2 & $\begin{array}{l}0,0 \\
07\end{array}$ & $\begin{array}{l}2,702 \\
(1,298-\end{array}$ \\
\hline
\end{tabular}


$5,625)$

\begin{tabular}{llllllll} 
& $\begin{array}{l}\text { Not Risk }(< \\
\text { 4) }\end{array}$ & 38 & 55 & 53 & 76,8 & & \\
& Total & 69 & 100 & 69 & 100 & & \\
\hline $\begin{array}{l}\text { Mari } \\
\text { etal }\end{array}$ & $\begin{array}{l}\text { Not } \\
\text { married/Di } \\
\text { us }\end{array}$ & 9 & 13 & 14 & 20,3 & & \\
vorced & & & & & 0,2 & $\begin{array}{l}0,589 \\
(0,236-\end{array}$ \\
& Married & 60 & 87 & 55 & 79,7 & & \\
& & & & & & \\
& Total & 69 & 100 & 69 & 100 & & \\
\hline
\end{tabular}

The results of the analysis of the relationship between age and the incidence of PMS in female patients at the Pekauman Health Center showed that the age at risk and the occurrence of PMS were 36 people $(52.2 \%)$ and 17 people $(24.6 \%)$ had an age at risk but no PMS occurred. Statistical test results using chi-square obtained $p$-value is $0.001(\mathrm{p}<0.005)$ which means that there is a significant difference in proportions between cases and controls, so there is a relationship between age and the incidence of PMS. And OR value of 3.337 which means that respondents who have an age at risk or $<20$ years or $>35$ years have a 3.337 times greater chance of being exposed to PMS compared to those not affected by PMS.

Respondents who had low education and occurred PMS numbered 37 people $(53.6 \%)$ while respondents with low education but $49 \mathrm{~S}$ did not occur $(71 \%)$. Chi-square statistical test results obtained $\mathrm{p}$-value is $0.035(\mathrm{p}<0.05)$ which can be interpreted that there is a significant difference in the proportion between cases and controls, so there is a relationship between education and STD events. With an OR value of 0.472 which means that respondents who do not occur PMS are twice as those that occur PMS.

Respondents who did not work and were diagnosed with STDs were 60 people (87\%), while those diagnosed with PMS were 59 people $(85.5 \%)$. The results of the chi-square statistical test showed the p-value was $0.805(\mathrm{p}>0.05)$ which could be interpreted that there was no meaningful 
difference in proportions between cases and controls, so there was no relationship between work and the incidence of PMS in female patients at Pekauman Health Center Banjarmasin .

Respondents with risk parity and PMS diagnosed amounted to 31 people (45\%), while respondents who did not occur PMS numbered 16 people (23.2\%). The result of the chi-square statistical test showed that the $\mathrm{p}$-value was 0.007 ( $\mathrm{p}<0.05$ ), which means there was a significant difference in proportion between cases and controls, so there was a relationship between parity and PMS events. And the OR value can be 2.702 so it can be concluded that respondents with parity who are at risk have a 2.702 times greater chance of getting PMS compared to respondents who are not exposed to PMS.

Respondents who were not married or divorced and PMS occurred amounted to 9 people (13\%), while respondents who did not occur PMS were 14 people (20.3\%). Chi-square statistical test results obtained $p$-value is 0.253 ( $p>0.05$ ) which means that there is no significant difference in proportions between cases and controls, so there is no relationship between marital status and STD events.

\section{Analysis Multivariat}

This analysis aims to obtain the variables that are most associated with the incidence of PMS in female patients at the Banjarmasin Pekauman Health Center. In multivariate analysis this is done in several stages, as follows:

a. Selection of independent variables as multivariate candidates

Candidates included in the multivariate are independent variables with a $\mathrm{p}$ value $<0.25$, while a $\mathrm{p}$ value $>0.25$ exits modeling. Bivariate test selection uses a simple logistic regression test. The test results on the independent variables can be seen in the table below: Analysis of Independent Variable Bivariate Selection Table with PMS Occurrence Using Simple Logistic Regression in Pekauman Health Center Banjarmasin

\begin{tabular}{|c|c|c|c|}
\hline No & Variable & $\begin{array}{l}p \text { - } \\
\text { value }\end{array}$ & Keterangan \\
\hline 1 & Age & 0,001 & $\begin{array}{l}\text { proceed to } \\
\text { multivariate }\end{array}$ \\
\hline 2 & $\begin{array}{l}\text { Level of } \\
\text { Education }\end{array}$ & 0,036 & $\begin{array}{l}\text { proceed } \\
\text { tomultivariat } \\
\mathrm{e}\end{array}$ \\
\hline 3 & Job & 0,805 & $\begin{array}{l}\text { removed } \\
\text { from } \\
\text { multivariate }\end{array}$ \\
\hline 4 & Parity & 0,008 & $\begin{array}{l}\text { proceed } \\
\text { tomultivariat } \\
\mathrm{e}\end{array}$ \\
\hline
\end{tabular}




\section{$5 \quad$ Marietal $\quad 0,257$ removed \\ Status from \\ multivariate}

The results of the analysis between the independent variables and the dependent variables show that the independent variables that have a $\mathrm{p}$ value of $<0.25$ are age, education and parity, while the occupational and marital status variables have a value of $p>0.25$ which means that the variable is excluded from multivariate modeling.

b. Multivariate modeling

1) First Modeling Results

First Multivariate Modeling Results Table Independent Variables with PMS Occurrence in Pekauman Health Center Banjarmasin

\begin{tabular}{lll}
\hline Variable & $p$-value & OR \\
\hline Age & 0,008 & 3,207 \\
Job & 0,002 & 0,288 \\
Parity & 0,089 & 2,162 \\
\hline
\end{tabular}

Based on the results of the first modeling multivariate analysis found that the value of p> 0.05 is a parity variable with a value of 0.089 . So that these variables are excluded from modeling.

2) Second Modeling Results

The Second Multivariate Model Variable Modeling Results Table with the incidence of PMS in Pekauman Health Center Banjarmasin

\begin{tabular}{lll}
\hline Variable & $p$-value & OR \\
\hline Age & 0,000 & 4,457 \\
level of & 0,005 & 0,323 \\
Education & & \\
\hline
\end{tabular}

Based on the results of the modeling after the parity variable is issued, the OR value will be calculated. If the OR value is $>10 \%$, then the parity variable is a confounding variable and will be re-entered into the modeling. The results of the calculation of OR values can be seen in the table below:

The results of the calculation table OR 


\begin{tabular}{|c|c|c|c|}
\hline $\begin{array}{l}\text { Variabl } \\
\mathrm{e}\end{array}$ & $\begin{array}{l}\text { OR } \\
\text { modelin } \\
\mathrm{g} \text { there } \\
\text { is a } \\
\text { parity } \\
\text { variable }\end{array}$ & $\begin{array}{l}\text { OR } \\
\text { modeling } \\
\text { no parity } \\
\text { variables }\end{array}$ & $\begin{array}{l}\text { chan } \\
\text { ge of } \\
\text { OR } \\
(\%)\end{array}$ \\
\hline Age & 3,207 & 4,457 & 38,9 \\
\hline $\begin{array}{l}\text { Level } \\
\text { og } \\
\text { Educat } \\
\text { ion }\end{array}$ & 0,288 & 0,323 & 12 \\
\hline
\end{tabular}

Based on these results it can be seen that after the parity variable was released there was a change in OR> $10 \%$. Thus the parity variable is a confounding variable and will be put back into the modeling.

3) Third Modeling Results

Third Modeling Table by Reinserting Parity Variables into Modeling

\begin{tabular}{lll}
\hline Variable & $p$-value & OR \\
\hline Age & 0,008 & 3,207 \\
$\begin{array}{l}\text { Level of } \\
\text { Education }\end{array}$ & 0,002 & 0,288 \\
Parity & 0,089 & 2,162
\end{tabular}

After the third modeling and seen no more p-values with values> 0.05 , then this modeling is the last model used in multivariate analysis.

c. Interpretation of Multivariate Result

Based on the results of multivariate analysis in the last modeling it was found that the age and education variables were variables related to the incidence of PMS. While the parity variable is not related to the incidence of PMS. The dominant variable is the age variable with an OR value of 3.207 after being controlled with educational variables. This means that the age of respondents who are at risk is 3.207 times more likely to be affected by STDs compared to respondents who have no-risk age.

\section{Qualitative Research}

This study aims to deepen the incidence of STDs that occur in female patients at the Pekauman Health Center in Banjarmasin by conducting in-depth interviews with several informants affected by STDs and informants from local health workers. 
In the first question addressed to informants affected by STDs regarding knowledge about STDs and ways of transmission, it was found that most of the informants knew about STDs from health workers after being examined so that it can be said that respondents' knowledge of STDs was still lacking. Like the one stated by the informant below:

“....it's a disease that can spread to our partners and transmission that I know through sexual contact...."

Informan 1, woman 35 years old (+)

“....PMS is a venereal disease, one of the signs of which is vaginal discharge and itching in the female area ... like I miss, after I was examined it turned out that the officer said I was exposed to PMS and transmitted through sexual contact....."

Informan 2, woman 27 years old (+)

Questions about medical history were obtained that informants were exposed to STDs due to risky sexual patterns, namely the use of condoms that are rarely used, especially for informants with jobs as Female Sex Workers (WPS). This was stated by the informant below:

“.... because my job is as a woman ... I have long worked in that place and change partners. So finally I got the disease ... especially since we rarely use condoms because customers are usually uncomfortable when using condoms...."

Informan 1, woman 35 years old

"...I often get vaginal discharge and arise warts in my female area and it hurts. I do work peddling sex sis ... so maybe yes contracted from my partners. When it comes to condoms, seldom miss because customers usually don't want to, so yeah, yes, yeah, yeah, because I'm looking for money..."

Informan 2, woman 27 years old

Regarding the attitude of the health workers, all informants stated that the attitude of the health workers when conducting the examination was considered friendly, good and polite as well as providing an explanation related to the results of the examination. The statement conveyed by the informant is as follows:

".....the clerk here is very friendly and kind. They give an explanation first before conducting an examination, so I am happy and comfortable to check here. Even though it's only at the puskesmas but I think it's complete here, and after checking they always explain the results in accordance with reality so I understand more about what happened to me ... obviously I feel satisfied mbak, if I'm not satisfied I definitely won't check again here ... hehehe....”

Informan 1, woman 35 years old

“.....officer here? Fine, if you give service. I also checked here from the beginning, sis ... the inspection process did not take long, if the results came out, immediately told. Anyway, I'm satisfied if you check here..."

Informan 2, woman 27 years old

Information obtained from health workers about sexual relationship behavior from informants, informants affected by STDs are not all who want to tell about their sexual behavior. 


\section{Discussion}

1. Relationship between respondent's age and incidence of PMS

Based on the analysis of the relationship between the age of the respondent and the incidence of PMS, it was found that the majority of respondents who were at risk and affected by PMS were 36 people (52.2\%). And the analysis results obtained p-value is 0.001 which means that there is a significant relationship between the age of the respondent with the incidence of PMS.

Age at risk shows someone's maturity that the more mature a person's age, the easier it is to make a decision. In addition, the age at risk of PMS is prone, this is consistent with the results of the analysis that the OR value is 3.337 which means that the age at risk is 3.337 times more likely to be affected by PMS compared to those not affected by PMS. This is caused by the maturity of the reproductive organs when a woman aged less than 20 years who is not yet anatomically ready for sexual intercourse while those over the age of 35 will be more susceptible to infection.

The results of other studies also indicate that the highest incidence of gonorrhea susceptible is between the ages of 15 - 35 years. From this it can be seen that the age factor greatly affects a person vulnerable to sexually transmitted diseases one of which is gonorrhea. Basically, women of this age have been active in sexual relations and younger women will be more vulnerable to contracting infectious diseases including gonorrhea infections[13].

2. Relationship between respondent's level education and incidence of PMS

The results showed that respondents with low education and diagnosed with PMS were 37 people $(53.6 \%)$ and those who were not diagnosed with PMS were 49 people $(71 \%)$. Statistical test results using the chi-square test obtained $p$ value is $0.035(p<0.05)$ which means that there is a relationship between education and the incidence of PMS.

Education is one of the determining factors in a person's lifestyle and status in society. The level of education possessed has a strong influence on one's behavior, assuming that the higher a person's education, the more understanding someone is in preventing sexually transmitted diseases[13].

It is also related to the identity of ordinary informants, where out of 5 ordinary informants there are 4 people with low education and 1 person with higher education. And informants who have junior high school education state that she works as a female sex worker and does not use condoms when dealing with her partner let alone changing partners frequently. This is stated in the statement below:

"....because my job is as a woman ... I have long worked in that place and change partners. So finally I got the disease ... especially since we rarely use condoms because customers are usually uncomfortable when using condoms...."

Informan 1, woman 35 years old

From the analysis results obtained an OR value of 0.472 , which means that the proportion of respondents who did not occur PMS was twice that that occurred by PMS

The higher one's education, the easier it is to receive information and can increase knowledge and insight in recognizing a problem, especially the problem of sexually transmitted diseases. 
According to Hutagalung in Hartono's research (2009) that education is very closely related to information about reproductive health received by a person so as to distinguish between right health behavior and wrong health behavior. This shows that low education has low knowledge of reproductive health[7].

This is consistent with the statement of one informant who has low education about how to anticipate the transmission of STDs after having sexual intercourse without using a condom. “....not using anything sis ... indeed I always offer to use a condom but many don't want it because it's uncomfortable too, but it feels .... but if people are like that how do I force myself to use condoms ... but not all customers, more do not use condoms..."

Informan 2, woman 27 years old

3. Relationship between respondent's Job and incidence of PMS

The results showed that the average woman who had a PMS examination and was diagnosed with PMS were those who did not work or were only housewives, 60 people (87\%). Chi-square statistical test results obtained p value is $0.805(\mathrm{p}>0.05)$ which means that there is no relationship between work and the incidence of PMS in female patients at Pekauman Health Center Banjarmasin.

Work is something that is done to earn a living or community livelihood with daily activities that will have more time to obtain information (Notoatmodjo, 2012). With these results, the assumption is that respondents who only work at home as housewives lack information about STDs or how they are transmitted. With broad insight, a person can prevent the transmission of sexually transmitted diseases [10].

While jobs that are likely to be related to STD events are people who work as female sex workers. As the results of interviews with several ordinary informants who stated that he was exposed to sexually transmitted diseases because it was his job as a female sex worker, as stated in the statement below:

“.... because my job is as a woman ... I have long worked in that place and change partners. So finally I got the disease ... especially since we rarely use condoms because customers are usually uncomfortable when using condoms...."

Informan 1, woman 35 years old "....I often get vaginal discharge and arise warts in my female area and it hurts. I do work peddling sex sis ... so maybe yes contracted from my partners. When it comes to condoms, seldom miss because customers usually don't want to, so yeah, yes, yeah, yeah, because I'm looking for money..."

Informan 2, woman 27 years old

Based on the statement, that certain jobs can transmit a balanced sexual disease by not using a condom during sexual intercourse, whereas work in general is not related to the incidence of STDs. However, counseling and monitoring of work as women sex workers need to be enhanced with experience in sexual relations.

4. Relationship between respondent's Parity and incidence of PMS

Parity describes the number of deliveries a woman has experienced, both live and stillbirths. The results showed that parity at risk and PMS occurred was 31 people (45\%). Chisquare statistical test results showed the p-value is $0.007(\mathrm{p}<0.05)$ which means that there is a relationship between parity and the incidence of PMS. 
The higher the parity or the more often a woman gives birth, the more vulnerable it is to be infected with a disease. This is consistent with the OR value obtained which is equal to 2.702 which means that parity at risk has a 2.702 times greater chance of being exposed to PMS when compared to parity that is not at risk.

In contrast to the identities obtained from research informants, only 2 out of five informants have children and are still classified as not at risk parity. The possibility that can influence the informant suffering from STDs is sexual behavior that is not good. This is illustrated by the explanation of one of the young WPS:

“.....approximately 3 months ago. I have been a sex worker for a long time, yeah ... more or less 2 years ... usually because of the economy, my family is from a difficult family. But I didn't think that I would get this disease ... I have never used a condom but I used a contraceptive injection..."

Informan 5, woman 18 years old

The information conveyed illustrates that parity does not have a major influence on the occurrence of STDs but rather towards poor sexual behavior.

Sexual behavior in humans can be interpreted as a complex activity and is not only limited to releasing tension through orgasm. Sexual intercourse without using a condom is an unsafe behavior from the transmission of sexually transmitted diseases[7].

5. Relationship between respondent's Marietal Status and incidence of PMS

The results showed that the most respondents were respondents who were married but there were 60 people $(87 \%)$ while the respondents who were not married / divorced and there were only 9 people $(13 \%)$. Chi-square test results obtained p-value is 0.253 (p>0.05) which means that there is no relationship between marital history with PMS events. And the greater proportion of respondents who were married occurred PMS compared to those who were not married.

This is not in accordance with the statement conveyed by Setyawulan (2007), that the incidence of PMS is higher in people who are not married, divorced or people who are separated from their families when compared to people who are married because their sexual needs are fulfilled[14].

The results of a study conducted by Purnamawati (2013) that marital status more than once with a history of divorce is a factor behind a person being a female sex worker and most likely to be affected by STDs [11].

Research conducted by Sari et.al (2012) on the incidence of gonorrhea infections in commercial sex workers in the localization of the Banjarbaruulin foundation stated that the most results were respondents who were not married, amounting to 42 people $(61.76 \%)$ and the reason they became CSWs was due to economic reasons. According to Lestari (2010) and Utami (2010) that women who work as CSWs are women who are not bound by legal marriage $[13,9,15]$.

The results of this study indicate that there is no relationship between marital status and STD events. However, the incidence of STDs can be caused by other factors such as risky sexual behavior, reasons for being a female sex worker and an environment that affects being a female sex worker. The environment in the Pekauman Region is a densely populated one and the region with the highest early marriage cases. The age of first time having sex can influence 
the occurrence of STDs, because the younger they have sex the more likely they are to have risky sex.

Information obtained from informants 3 informants stated that they had sex at the age 0f $<20$ years old. This concludes that marital status is not a factor related to incidence of STD but the age at which first intercourse will be related to incidence of STD.

6. The Most dominant factor related to the incidence of PMS

Based on the results of multivariate modeling analysis found that the most dominant factor related to the incidence of PMS is the age variable with an OR value of 3.207, which means that age at risk has a 3.207 times greater chance of being exposed to PMS compared to respondents who are not exposed to PMS.

Age can show one's maturity that the more mature a person is, the easier it is to make decisions, especially in the prevention and treatment of STDs.

The results of interviews with ordinary informants also showed that the average informants affected by PMS only knew a small portion of PMS and that was also obtained from the explanation of health workers after conducting PMS examinations.

Based on the results of research that has been done, there are still a number of factors causing STD events so that it is expected that health workers can continue to make promotional efforts in the handling of STDs in women.

\section{REFERENCE}

[1] Afriana, Nurhalina. Faktor-Faktor yang Berhubungan dengan Kejadian Infeksi Gonore pada Wanita Penjaja Seks Komersial di 16 Kabupaten/Kota Indonesia (analisa data STBP (2011).

[2] Artika, Millus Dewi. Gambaran Tingkat Pengetahuan Perempuan Pekerja Seks Komersial Mengenai Penyakit Menular Seksual Di Desa Mertan Kecamatan Bendosari Kabupaten Sukoharjo (2009).

[3]Dinas Kesehatan Kota Banjarmasin. Prevalensi Infeksi Menular Seksual. Banjarmasin: Dinas Kesehatan Kota Banjarmasin (2011).

[4] Dinas Kesehatan Provinsi Kalimantan SelatanPrevalensi Infeksi Penyakit Menular Seksual. Banjarmasin : Dinas Kesehatan Provinsi Banjarmasin (2010).

[5] Dit.Jend. Dep.Kes.R.I. Estimasi Nasional Infeksi HIV pada Orang Dewasa Indonesia, Dep. Kes,. Jakarta (2003).

[6] Ditjen PP \& PL Kemenkes RI. Statistik Kasus HIV/AIDS di Indonesia.

[7] Hartanto D. Aku Memang Gay [Skripsi] Yogyakarta: Fakultas Ilmu Pendidikan UNY (2006).

[8] Kemenkes RI. Data dan Informasi Tahun 2014 (ProfilKesehatan Indonesia). Jakarta (2015).

[9] Lestari, F.A. Dinamika Mental pada Pekerja Seks Komersial (PSK) dalam Menghadapi Pembubaran Lokalisasi di Kabupaten Blitar Malang: Univ. Islam Negeri Maulana Malik Ibrahim, (2010).

[10] Notoatmodjo, Soekidjo, Metodologi Penelitian Kesehatan. Jakarta : Rineka Cipta (2012). 
[11] Purnamawati, Dewi. Perilaku Pencegahan Penyakit Menular Seksual di Kalangan Wanita Pekerja Seksual Langsung. Jurnal Kesehatan Masyarakat Nasional Vol 7 No 11 (2013).

[12] Reviliana, Pipit Artathi, Eka Suryan dari dan Warni Fridayanti. Beberapa Faktor yang Mempengaruhi Tingginya Kejadian PMS Di Lokalisasi Gang Sadar Baturaden Kab. Banyumas. Jurnal Ilmiah Kebidanan Vol 3 No 1 Edisi Juni 2012 (2011).

[13] Sari, Putri Kartika, H.M.Muslim, Safarianti Ulfah. Incident of Gonorrhoeae Infection on Commercial Sex Workers at Ex-Localization Pembatuan Subdistrict Landasan Ulin Banjarbaru. Jurnal BUSKI Vol 4 No1 Juni 2012 (2012).

[14] Setyawulan. Hubungan praktek pencegahan penyakit menular seksual dengan kejadian penyakit menular seksual (on-line). Terdapat pada: http//digilib.unimus.ac.id/download.php?i $\mathrm{d}=2404$ (2007).

[15] Utami, Mardina Diah. Manajemen konflik pada wanita pekerja seks komersial yang berkeluarga (on-line). Terdapat pada : http//eprints.undip.ac.id/11120/1/INTISARI.Pdf (2010). 